\title{
Volatile and precious elements in plutonic and volcanic rocks: Implications for epithermal- and porphyry-style mineralisation, western Thrace, NE Greece
}

\author{
JAN J. FALKENBERG ${ }^{1}$, MANUEL KEITH ${ }^{2}$, KARSTEN M. \\ HAASE $^{2}$, PANAGIOTIS C. VOUDOURIS ${ }^{3}$ AND MARCEL \\ REGELOUS $^{2}$ \\ ${ }^{1}$ GeoZentrum Nordbayern, Friedrich-Alexander Universität \\ (FAU), Erlangen-Nürnberg \\ ${ }^{2}$ GeoZentrum Nordbayern, Friedrich-Alexander-Universität \\ (FAU) Erlangen-Nürnberg \\ ${ }^{3}$ Department of Mineralogy-Petrology, University of Athens \\ Presenting Author: jan.falkenberg@fau.de
}

Epithermal and porphyry ore deposits related to subduction zone magmatism are important economic resources for $\mathrm{Cu}$, Se, $\mathrm{Mo}, \mathrm{Te}, \mathrm{Ag}, \mathrm{Re}, \mathrm{Au}$ and $\mathrm{Bi}$. However, the magmatic processes that control whether an arc segment is barren or mineralized are controversial. The mineralisations of Thrace, NE Greece, are related to calc-alkaline volcanic/plutonic rocks in a continental arc setting [1]. Hence, this area represents an exceptional case study site to define the magmatic prerequisites for metal and sulfur enrichment.

We present ICP-MS and HG-AFS data of volatile (e.g., Se, Te, $\mathrm{Bi}$ ) and precious (e.g., $\mathrm{Au}, \mathrm{Ag}, \mathrm{Re}, \mathrm{Pd}, \mathrm{Pt}$ ) elements of unaltered volcanic/plutonic rocks from Thrace, which we combine with EPMA measurements of minerals (e.g., apatite, amphibole), magmatic sulfides (e.g., pyrrhotite) and melt inclusions. This allows us to estimate the temperature, pressure, $f \mathrm{O}_{2}$ conditions and $\mathrm{H}_{2} \mathrm{O}$ contents at the onset of sulfur and volatile saturation during magma differentiation and to assess their effect on the fractionation of volatile and precious elements.

Preliminary results suggest that the low $\mathrm{Sr} / \mathrm{Y}(<50)$ magmas had $\mathrm{Pd} / \mathrm{Pt}$ and $\mathrm{Pd} / \mathrm{MgO}$ signatures typical of $\mathrm{Cu}-\mathrm{Au}$ fertile systems [2]. They were characterized by high $\mathrm{H}_{2} \mathrm{O}$ contents $(2-6$ wt.\%), elevated $f \mathrm{O}_{2}(\mathrm{FMQ}=+1)$, low $\mathrm{S}(<30-90 \mathrm{ppm})$ and low $\mathrm{Cl}$ contents (0.1-0.5 wt.\%) indicating that an aqueous volatile phase likely exsolved from the magma during an early stage prior to $\mathrm{S}$ saturation indicated by decreasing $\mathrm{Cu} / \mathrm{Ag}, \mathrm{Pd} / \mathrm{Pt}$ and $\mathrm{Pd} / \mathrm{Cu}$ ratios. Hence, scavenging of sulfide cumulates formed by early $\mathrm{S}$ saturation is not a mandatory magmatic process for mineralisations in Thrace [3]. Instead, we propose that volatile exsolution before the onset of sulfur saturation may increase the ore-forming potential of arc magmatic systems.

[1] Voudouris et al. (2019): Porphyry and epithermal deposits in Greece: An overview, new discoveries, and mineralogical constraints on their genesis. In: Ore Geology Reviews 107

[2] Park et al. (2019): Chalcophile element fertility and the formation of porphyry $\mathrm{Cu} \pm \mathrm{Au}$ deposits. In: Miner Deposita 54 (5)

[3] Rezeau and Jagoutz (2020): The importance of $\mathrm{H} 2 \mathrm{O}$ in arc magmas for the formation of porphyry $\mathrm{Cu}$ deposits: In: Ore Geology Reviews 126 